\title{
Journal of Applied Linguistics and Literacy
}

\section{https://jurnal.unigal.ac.id/index.php/jall/index}

ISSN: 2598-8530

February 2018, Vol. 2 No. 1

English Education Program

Faculty of Teacher Training and Education

Galuh University

\begin{tabular}{|ccc|}
\hline Received: & Accepted: & Published: \\
\hline October 2017 & December 2017 & February 2018 \\
\hline
\end{tabular}

\section{THE REALIZATION OF ATTITUDE ANALYSIS ON MALE AND FEMALE SECOND-YEAR STUDENTS' NARRATIVE TEXTS}

\author{
Vivi Putriyantina \\ viepuput95@gmail.com \\ Galuh University, Ciamis, Indonesia \\ Iskhak Said \\ Galuh University, Ciamis, Indonesia \\ iskhak.said@yahoo.com
}

\begin{abstract}
This study was aimed to find out the realization of attitude analysis in the students narrative texts. The writers applied qualitative design particularly descriptive qualitative as the method. The results asserted 421 clauses realized on male and female second-year students' narrative texts. There were 150 attitudes which consisted of 51 attitudes on male narrative texts and 99 attitudes on female narrative texts. Meanwhile, those covered 76 affects, 24 judgements, and 50 appreciations realized on male and female second-year students narrative texts. From those aspects, the most dominant aspect was realized by affect. In conclusion, the realization of attitude analysis on male and female second-year students' narrative texts was realized 150 items, which were dominated by 76 items $(51 \%)$ realization of affect. Finally, it is expected that through learning attitude, the students can improve their writing skill and choose the proper vocabularies in composing English text. Besides, it is suggested for further researchers to enrich their research by conducting research with the full-package of appraisal system which cover affect, engagement, and graduation.
\end{abstract}

Keywords: SFL, Interpersonal meaning, Appraisal System

\section{INTRODUCTION}

Every single written word that is typed in a language has its meaning itself even some people prefer to deliver their message by uttering their utterance rather than writing 
their message. In line with statement aforementioned, language use is functional; that its function is to make meanings; that these meanings are influenced by the social and cultural context in which they are exchanged; and that the process of using language is a semiotic process, a process of making meaning by choosing (Eggins, 1994, p.2; 2004, p. 2). She (1994, p. 2; 2004, p. 81) also highlighted that language itself is organized to make meanings about fields, modes, and tenors because those are the meanings that the speakers or listeners want and need to make it in interacting each other in the world. In harmony with Eggins's points of view, it summed up that English Foreign Language (henceforward EFL) learner who learns English as his or her subject has to know the meaning varieties. Therefore, he or she does not make mistake in interpreting their texts' meaning.

Dealing with the meanings aforementioned, there are three metafunctional lines of meanings that are developed by Halliday (2004, pp. 29-30) that meanings contained in a text consisted of Ideational meaning, Interpersonal meaning, and Textual meaning. Those are derived from the latest grammar system which is developed in Systemic Functional Grammar (henceforward SFG) that is adapted from Systemic Functional Linguistics (henceforward SFL). Moreover, the usage of SFG covered by an approach namely Discourse Analysis (henceforward DA). In SFL, it covers not only contexts but also metafunctions. One of them is Interpersonal metafunction.

Concerning interpersonal meaning, Butt et al., (2000, p. 5) state that interpersonal meaning relates to tenor which functions to interact or to express a point of view. In the meantime, the function of interpersonal metafunction is to enact relationship which refers to speakers' attitude and judgement (Martin and Rose, 2007, p. 17). From the theories, interpersonal metafunction encodes on an evaluation that negotiates attitudes. On the other hand, the EFL learner, himself or herself, is often encountered the interpersonal text which needs to be comprehended and properly analyzed by a proper analysis framework as the so-called Appraisal System analysis.

Appraisal concerned with evaluation, the kinds of attitudes that are negotiated in a text, the strength of feelings involved and the ways in which values are sourced and readers aligned (Martin and Rose, 2007, p. 22). In line with the previous statement, Martin \& Rose (2007, p. 24) highlighted three basic options for appraisal analysis as the so-called the appraisal system. That system contained attitude, engagement, and graduation.

Firstly, attitude which covers affect at which it refers to resources for expressing feelings, judgement for judging characters and resources for valuing the worth of things 
called appreciation. Secondly, engagement describes how strongly the feeling about someone or something. It covers monogloss (nondialogic) means one voice and heterogloss (dialogic) means more than one voice.

Furthermore, monogloss is established by contra and expand (Martin and Rose, 2007, pp. 25-29; Martin and White, 2005, pp. 33-38). Finally, graduation describes what was said by people (Martin and Rose, 2007, p. 17; Butt et al., 2000, p. 5). It deals with grading evaluation which covers force (intensify/tone down) and focuses (strengthen/weaken). In harmony with the present study, the regions of appraisal system which is used to analyze the text are the attitude. It covers affect (emotional reaction), judgement (assessing behavior), and appreciation (assessing the value of the things). Furthermore, the texts which are analyzed carried out as the source of data are the sophomores' writing products in the form of narrative texts. It is as one of lecture in the third semester and those are analyzed based on its attitude system analysis.

There are several studies on the basic region of appraisal used to support the present study. Some previous studies carried out by the previous researchers also focused on appraisal system as one of the branches of SFL. The first previous study was carried out by Liu (2003) entitled: "Evaluation in Chinese University EFL Students' English Argumentative Writing: An Appraisal Study". The second previous studies were undertaken by Macken (2003) entitled: "Appraisal and Special Instructiveness of Narrative". The third previous studies were conducted by Page (2003) entitled: “An Analysis of Appraisal in Childbirth Narratives with Special Consideration of Gender and Storytelling Style" and the fourth previous studies was carried out by Liu and Thompson (2009) entitled: “Attitude in Students' Argumentative Writing: A Contrastive Perspective”. In harmony with the previous studies aforementioned, all of them have relation with the present study. Those previous studies focus on analyzing the text through appraisal system analysis. In addition, those previous studies provide appropriate resources to be engaged in the present study, yet those previous studies have not conducted appraisal system research in educational sector especially in a private university in East Priangan.

\section{METHOD}

The present study was designed by employing a descriptive qualitative research methodology at which it concerned with the process and tended to analyze and interpret the comprehensive visual data than a number to know what their participants do in this study. Besides, it investigated the quality of relationships, activities, situations, or materials 
(Fraenkel, Wallen and Hyun, 2012, pp. 426-427). One of qualitative research focused on is material, it could be understood as the analysis through text which the research could be explored more in detail about what went on in a certain subject matter. Further discussion, it could be the analysis of diaries, text book, and genre. In relation to the present study, the writer analyzed one genre in the form of narrative text. Furthermore, it concerned to analyze the data for description by using text analysis and interpret the larger meaning of the findings. Moreover, the data of this study were in the form of narrative texts composed by the second-year students in the third-semester of English Education Program in Galuh University Ciamis.

As the purpose, those texts were analyzed and interpreted by using functional grammar theory of appraisal system as proposed by Martin and White (2005). In addition, to analyze the data for description of text analysis and interpret the larger meaning of the findings, qualitative descriptive could be applied (Creswell, 2012, p.16). Based on the aforementioned statement, the writers analyzed attitude in the second-year students' narrative texts. The data described by using words in the description. Thus, the writers were able to explore the central phenomenon wider by using words.

\section{FINDINGS AND DISCUSSION}

The writers had described the findings of attitude distribution on six selected narrative texts. Dealing with the results, those could be summed up that the realization of attitude covered affect, judgement, and appreciation which were distributed by 76 items of affect, 24 items of judgement, and 5 items of appreciation. From the three distributions of attitude analysis above, those could be summarized and figured out by table 3.1.

Table 3.1: The summary of attitude distribution

\begin{tabular}{|c|c|c|c|c|}
\hline Attitude & Tittle of the Text & Category/Code & Numbers & Percentage \\
\hline \multirow{4}{*}{} & The Man from the Star & High/F1 & 34 & $45 \%$ \\
\cline { 2 - 5 } & $\begin{array}{c}\text { The Mouse Deer and } \\
\text { Crocodile }\end{array}$ & High/M1 & 12 & $16 \%$ \\
\cline { 2 - 5 } & Piggy & Middle/F2 & 7 & $9 \%$ \\
\cline { 2 - 5 } & Alladin & Middle/M2 & 8 & $10 \%$ \\
\cline { 2 - 5 } & Pinocchio & Low/F3 & 10 & $13 \%$ \\
\cline { 2 - 5 } & The Apple Tree and the & Low/M3 & 5 & $7 \%$ \\
\hline
\end{tabular}




\begin{tabular}{|c|c|c|c|c|}
\hline \multicolumn{3}{|c|}{ Boy } & \multirow[b]{2}{*}{76} & \multirow[b]{2}{*}{$100 \%$} \\
\hline \multicolumn{3}{|c|}{ Total of affect } & & \\
\hline \multirow{6}{*}{ Judgement } & The Man from the Star & High/F1 & 12 & $50 \%$ \\
\hline & $\begin{array}{c}\text { The Mouse Deer and } \\
\text { Crocodile }\end{array}$ & High/M1 & 2 & $8 \%$ \\
\hline & Piggy & Middle/F2 & 1 & $4 \%$ \\
\hline & Alladin & Middle/M2 & 3 & $13 \%$ \\
\hline & Pinocchio & Low/F3 & 5 & $21 \%$ \\
\hline & $\begin{array}{c}\text { The Apple Tree and the } \\
\text { Boy }\end{array}$ & Low/M3 & 1 & $4 \%$ \\
\hline \multicolumn{3}{|c|}{ Total of judgement } & 24 & $100 \%$ \\
\hline \multirow{6}{*}{ Appreciation } & The Man from the Star & High/F1 & 19 & $38 \%$ \\
\hline & $\begin{array}{c}\text { The Mouse Deer and } \\
\text { Crocodile }\end{array}$ & High/M1 & 7 & $14 \%$ \\
\hline & Piggy & Middle/F2 & 6 & $12 \%$ \\
\hline & Alladin & Middle/M2 & 8 & $16 \%$ \\
\hline & Pinocchio & Low/F3 & 5 & $10 \%$ \\
\hline & $\begin{array}{c}\text { The Apple Tree and the } \\
\text { Boy }\end{array}$ & Low/M3 & 5 & $10 \%$ \\
\hline \multicolumn{3}{|c|}{ Total of Appreciation } & 50 & $100 \%$ \\
\hline \multicolumn{3}{|c|}{ TOTAL OF ATTITUDE } & 150 & $100 \%$ \\
\hline
\end{tabular}

From the table 3.1, it was concluded that six texts performed 76 items of affect, 24 items of judgement, and 50 items of appreciation. Those total number of attitude realization were calculated in table 3.2 .

Table 3.3: The calculation of attitude realization

\begin{tabular}{|l|c|c|}
\hline \multicolumn{1}{|c|}{ Attitude } & Number & Percentage \\
\hline Affect & 76 & $51 \%$ \\
\hline Judgement & 24 & $16 \%$ \\
\hline Appreciation & 50 & $33 \%$ \\
\hline \multicolumn{1}{|c|}{ TOTAL } & $\mathbf{1 5 0}$ & $\mathbf{1 0 0 \%}$ \\
\hline
\end{tabular}


The Differences in Performing Attitude Between Male and Female Second-Year Students' Narrative Texts

3.3 The comparing calculation of male and female attitude

\begin{tabular}{|c|c|c|}
\hline Gender & Number & Percentage \\
\hline Male & 51 & $34 \%$ \\
\hline Female & 99 & $66 \%$ \\
\hline TOTAL & 150 & $100 \%$ \\
\hline
\end{tabular}

Table 3.3 showed male students tend to perform 54 items (34\%) of attitude while female performed 99 items (66\%), it could be concluded that among college graduates with similar communication skills, females use more written communication as a means of establishing rapport more than males as research done by Boser et al., (1991, p. 13). It was proven that female performed $66 \%$ of attitude rather than male who performed $34 \%$. It meant than female was bigger than male. Moreover, females tend to write longer responses to express themselves by complete thoughts (sentences). It was proven by performing 51 items of affect in which it dealt with feeling, 18 of judgement which encompassed meanings that served to appraise human behavior, and 30 items of appreciation which concerned with a set of resources referred to as social valuation. While on the other hand, male students performed attitude less than what females did.

In short, differences in the way women and men speak and write are unquestionable; they can be observed at every level of organization of language and speech: on the morphological, lexical and syntactic planes, and in the use of different styles and communication strategies. In the forthcoming section, it delineated and explicated the findings and the previous study as the comparison of both studies.

\section{CONCLUSIONS}

Within the present systemic functional linguistics (as the so-called SFL), appraisal system had been applied. Systemic functional linguistics investigated a descriptive and interpretive framework for viewing language as a strategic. Besides, it referred to variously regions as appraisal, stance, and evaluation. In relation to the present study, SFL viewed that language was functional. Later on, these meaning were influenced by the social and cultural context. It was referred to variously as appraisal, stance, and evaluation (Bloor and 
Bloor, 2004, p. 232). Appraisal could locate as an interpersonal system at the level of discourse semantics (Martin and White, 2005, p. 33).

The appraisal system focused upon the students' narrative texts and tried to investigate attitude analysis as branches of appraisal system. The present study had revealed the attitude as well as the realization represented within narrative texts entitled "The Man from the Star", "The Mouse Deer and Crocodile", "Piggy", "Alladin", "Pinocchio", and "The Apple Tree and the Boy" through several analytical steps. The realization was represented within the narrative texts under investigation beyond emotion to deal more comprehensively with feelings, including affect, judgement, and appreciation (Martin and White, 2005, p. 40). This was simultaneously established a system for negotiating or evaluating people's character, and people's feeling on narrative texts.

This study adopted particular value for negotiating social relationship by telling the listener or the readers how their feel about things and people. In relation to the present study, appraisal here was a system for negotiating or evaluating people's characters, and people's feelings on narrative texts. Even though, there were some weaknesses which were need to be solved by further research.

\section{REFERENCES}

Bloor, M., \& Bloor, T. (2004). The functional analysis of english: $2^{\text {nd }}$ edition. United State of America: Arnorld Publisher.

Butt, D., Fahey, R., Feez, S., Spinks, S., \& Yollap, C. (2000). Using functional grammar: An explorer's guide. Macquarie University-Sydney: National Centre for English Language Teaching and Research.

Boser, A, J., Wiley, P, D., \& Clark, S, B. (1991). Gender differences: Let's see them in writing. Mid-South Educational Research Association, 1-16. Retrieved on December $27^{\text {th }}$ 2016 from: https://www.google.co.id/search?rediresc=\&client=msandroidasus\&hl=inID\&safe=i mages\&oe $=$ utf $-8 \& q=$ genderdifferences: letsseetheminwriting knowvile.odf\&source $=$ android-browser-type $\&$ qsubts $=1482857798787 \&$ devloc $=0$

Creswell. J. W. (2012). Educational research: Planning, conducting, and evaluating quantitative and qualitative research, $4^{\text {th }}$ edition. USA: Pearson Education.

Eggins, S. (1994). An introduction to systemic functional linguistics. London: Pinter Publisher Ltd.

Eggins, S. (2004). An introduction to systemic functional linguistics: Second edition. London: Pinter Publisher Ltd. 
Fairclough, N. (2003). Analysing discourse: Textual analysis for social research. New York: Routledge.

Fraenkel, J. R., Wallen, N. E., \& Hyun, H. H . (2012). How to design and evaluate research in education: $8^{\text {th }}$ edition. New York: The McGraw-.

Halliday, M.A.K., \& Matthiessen, C.M.I.M. (2004). An introduction to functional grammar: $3^{\text {rd }}$ edition. USA: Oxford University Press Inc.

Macken, M. (2003). Appraisal and special instructiveness of narrative. Electronic Journal of Foreign Language Teaching, 23(2), 285-312. Retrieved on August $15^{\text {th }}, 2016$ from http://www.grammatics.com/appraisal/textSpecial/macken-horariknarrative.pdf

Martin, J. R., \& Rose, D. (2007). Working with discourse, meaning beyond the clause, $2^{\text {nd }}$ edition. London: Continuum International Publishing Group.

Martin, J. R., \& White, P. R. R. (2005). The language of evaluation appraisal in English. Britain: Palgrave Macmillan Press.

Rukmini, D. (2007). The rhetorical development realizations of the reading texts of the senior high school English textbooks. Unpublished Dissertation. Semarang: Semarang State University (UNNES).

Xinghua, L. (2003). Evaluation in Chinese university EFL students' English argumentative writing: An appraisal study. Electronic Journal of Foreign Language Teaching. 10(1). 40-53. Retrieved on June $17^{\text {th }}, 2016$ from https://www.google.co.id/search?redir_esc=\&client=ms-androidasus\&hl=in-

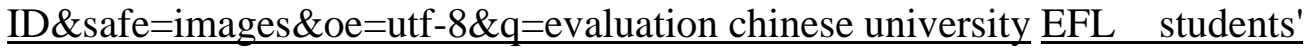
english argumentative writing an appraisal\&source=androidbrowser-

Xinghua, L., \& Thompson, P. (2009). Attitude in students' argumentative writing: A constrative perspective. University of Reading Language Studies Working Paper. 1, 3-15. Retrieved on November $16^{\text {th }}$, 2016 from: http://www.reading.ac.uk/internal/appling/Liu_and 